\title{
Effects of Bilateral Real Exchange Rate on Sino-Nigeria Trade: An ARDL Cointegration Approach
}

\author{
Julio Felippe Bicudo ${ }^{1} \&$ Nnanna P. Azu ${ }^{1}$ \\ ${ }^{1}$ School of International Economics and Trade, Dongbei University of Finance and Economics, Dalian, China \\ Correspondence: Nnanna P. Azu, School of International Economics and Trade, Dongbei University of Finance \\ and Economics, Dalian, China. E-mail: phil4azu@yahoo.com
}

Received: May 19, 2018

Accepted: June 8, 2018

Online Published: June 15, 2018

doi:10.5539/ijef.v10n7p125

URL: https://doi.org/10.5539/ijef.v10n7p125

\begin{abstract}
This research is motivated to scrutinise the effects of real bilateral exchange rate fluctuation on China-Nigeria bilateral trade, taking into consideration volatility and third country's bilateral exchange rate effect to determine their consequences. Due to its robustness in time series analyses, an ARDL approach to co-integration was used to determine the long-and short-runs effects. Both export and import were considered separately. Outcome revealed that Nigeria's import from China responds negatively to real bilateral exchange rate increase just as it does to its volatility. Her export to China reacts positively on both front, most especially in the short-run. Japan was integrated as a third country in this research due to her competing presence in Nigerian market. Third country's real bilateral exchange rate play prominent but negative role in China-Nigeria trade, and is mostly effective in the long-run. With the absolute value of the co-efficient of real bilateral exchange rate greater than one, depreciating the Naira against the Renminbi will tend to ameliorate the negative balance of trade Nigeria has with China. Finally, democratic regime was found to be very essential in enhancing international business.
\end{abstract}

Keywords: real exchange rate, ARDL, China-Nigeria, import, export, third country's effects

\section{Introduction}

Current statistics indicates that China is one of the principal exporting nations in the world surpassing USA as the largest trading nation when her trade hit over US\$4.16trn in 2013 (Anderlini \& Hornby, 2014; Monaghan, 2014). Her economy is hugely dependent on trade (Qazi 2012) and most interestingly has recorded large trade surplus over the decade while economic growth surges. Amid China's increasing global trade, Ariuna (2015) noticed that the past decade has witnessed a growing trade relation with Africa, with Piagato and Tang (2015) categorically revealing that China has become largest trading partner to Africa. Though not currently the major trading partner, her impact in Nigeria has been overwhelming even with persistence and intensified substantial trade imbalance, and many have envisaged that this trade imbalance had been a structural problem in Nigeria's trade relation with China and to large extent common to Africa (See Nabin, 2009; Kabassi, 2012; Agubamah, 2014; Udeala, 2013 and Azu \& Eche, 2016).

However, Abdol (2009) and Tang (2008) has attributed most bilateral trade deficit with China to existing China's exchange rate regime as lower RMB exchange has promoted growth in China and harmed the trade partners' economies but Mckinnon (2006) argues that the fundamental cause of China's excessive trade surplus with most trade partners like United States is US excess consumption coupled with China's excess saving rather than its exchange rate regime. It is well documented that China pegged her currency against the US dollar and despite her economic progress, government have done little or less to allow the currency to appreciate. Zhang (2001) and Zhang (1999) assessed different reforms in China's foreign exchange market and further concluded that the devaluation of the renminbi has been encouraging China's export significantly and Tang (2003) suggested that its import is strongly correlated to economic activities and relative prices. Unlike China, exchange rate in Nigeria is floating, and the naira has depreciated constantly over the last two decades, and both export and import improved significantly within this period. Igue and Ogunleye (2014) implied that depreciation of Nigeria currency improves its trade balance but Umoru and Oseme (2013) and Jibrilla and Shehu (2015) argued such improvement in Nigeria trade balance is not instant with Nigeria's currency depreciation.

Be as it may, with exchange rate management in China and Nigeria, how does the bilateral trade between the two 
nations be affected? Both countries have different exchange rate regimes but their bilateral trade seems to be on the increase over the years. Olugbenga and Oluwole (2008) cited that decline in Nigeria exchange rate encourages export to USA, while increasing volatility would adversely affect export demand. In addition, Tharaka (1999) and Vieria et al. (2013) also added that it impacts negatively on economic development. Will such submission be consistent with the happening in Nigeria-China trade relation? Though Jibrilla and Shehu (2015) found bidirectional causal relationship between changes in exchange rate and balance of trade, they think depreciation of naira does little to improve Nigeria trade balance.

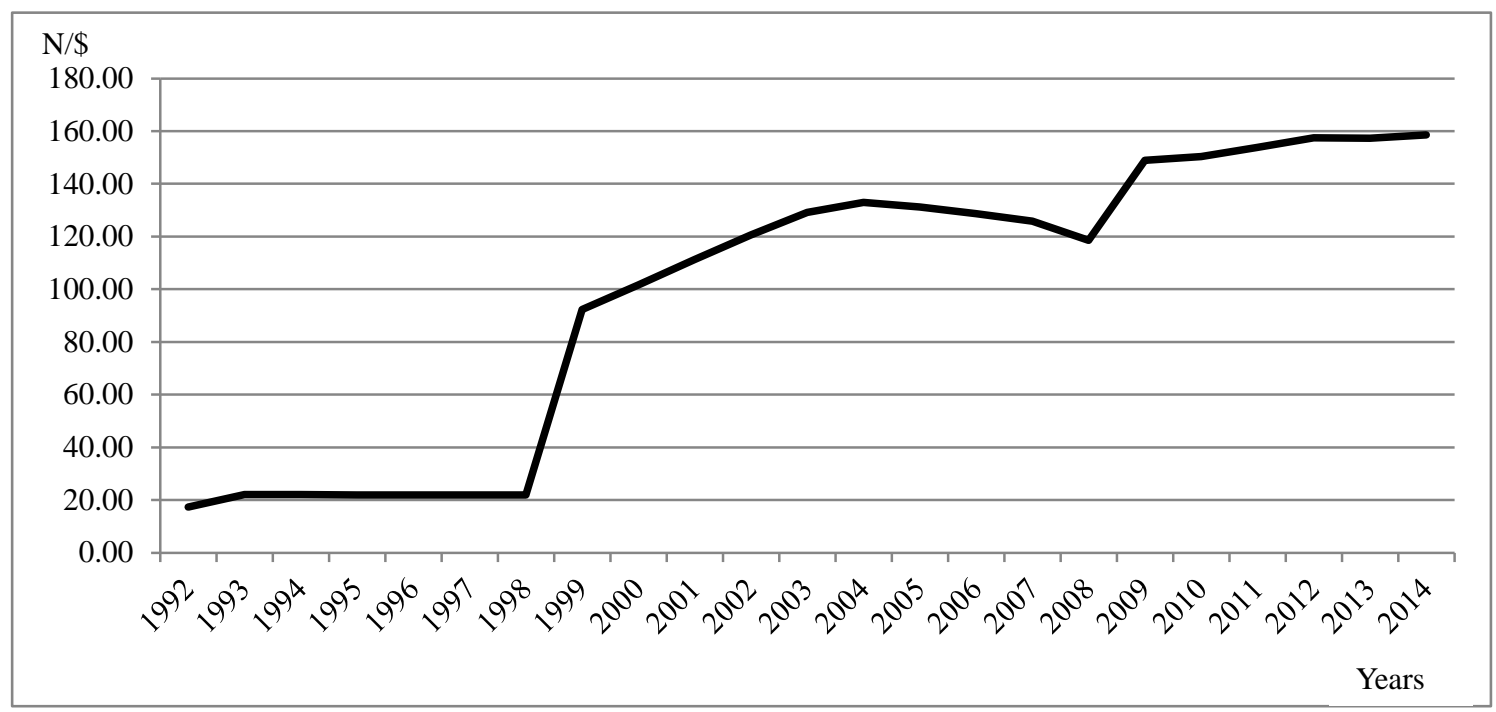

Figure 1. Naira per Dollar exchange rate

Source: IMF-International Financial Statistics.

Most recent academic researches on Nigeria exchange rate regimes (Shehu 2010, Umoru and Oseme 2013, Igue and Ogunleye 2014, Jibrilla and Shehu 2015) must have contributed to the existing literature but their approaches could not be considered to be robust. Besides, the sharp drop of naira against dollar as envisage in Fig 1 represent an obvious uncertainty at this period which could cause adverse consequences in Nigeria's external businesses. With that in mind, this piece of research work will concentrate on examining the effects of bilateral exchange rate movement on China-Nigeria bilateral trade relation, also considering the effects of exchange rate volatility and third country's exchange rate. The upshot of third country's effect on China-Nigeria bilateral trade have been given less or no thought. In this regard, the researchers will take Japan as the major competitor to China in Nigerian market and so they are. Also, democratic regime has been viewed to have created enabling business environment which does not only motivate inflow of FDI in Nigeria (Muhammad, Azu, \& Oko 2018) but also could improve bilateral trade relations, hence will be taken into consideration in this paper. With export and import considered separately the research will apply ARDL approach to cointegration to determine the long-and short-runs effects.

The remaining part of the research work will be segregated into four sections; section two will centre on reviewing the opinions of different authors in this field, section three will talk about the methodology used in data analysis, while section four will concentrate on empirical analysis to determine the long-and short-runs co-efficient of the variables in use with brief discussion of the outcome and lastly, section five is the concluding part.

\section{Literature Review}

There is handful literature that gave insights in exchange rate fluctuation, volatility and its relation to import and export. Some of which extended to further explain its impact on economic growth and development (Tharaka, 1999; Vieria et al., 2013; Manalo, Perera, \& Rees, 2015). The main argument in this section will be focused on various authors' view on the effect of bilateral exchange rate on bilateral trade, also considering the contributory effect of unpredictability of exchange rate towards trade (import and export) between nations and its relevance towards ameliorating trade balances.

Conversely, Akhtar and Hilton (1984) in their effort to assess the influence of Dollar-Dutch uncertainty as it 
affects US-Germany trade, reached conclusion that volatility in exchange rate is disadvantageous to transnational trade movements. Serial studies by Cushman (1983, 1986 and 1988) which focused on the effect of exchange volatility on bilateral trade, revealed that there are negative effects. Literarily, fluctuations in exchange rate brings uncertainty in exchange rate and most international traders would not like to be exposed much to such risks, hence hindering the enhancement of trade across countries mostly caused by indecision. Supported by Serenis and Tsounis (2014) which found that that there is overall significant statistical negative effect from volatility on export. Other researchers who have factually reported similar results in their empirical studies includes but not limited to Peree and Steinherr (1989), Chowdhurry (1993), Kim and Lee (1996), Dell'Ariccia (1999), Arize et al. (2000), Doganlar (2002), Bahmani-Oskooee (2002). Olugbenga and Oluwole (2008) also cited that depreciation in naira (Nigeria's currency) exchange rate would encourage export to USA, while increasing volatility would adversely affect export demand, in concordance to Shehu (2010) and Hassan (2013).

In another dimension, Baak (2008) conclude that exchange rate volatility turns out to adversely stimulate China's export to United States but seems not have much influence on United States' export to China. Invariably, implying that exchange rate volatility could affect an export to a given nation but would have no or less influence on import from the same trading partner. Similarly, Baek (2013) has it that South Korea's exports and imports are comparatively delicate and less responsive to bilateral exchange rate in the long-run, but otherwise in the short-run. Serenis and Serenis (2010) based on selected Euro countries and sector analysis, suggest a mixed relationship of volatility to trade; in part they believe that volatility does not have major effects but depends on sectors and countries much to the believe of Ozturk (2006). Aguirre et al. (2007) detected no significant relationship. Also, Serenis and Serenis (2008) support that exchange rate volatility has no major effect on trade growth.

Another research by Bahmani-Oskooee, Harvey, and Hegerly (2013) that obtained contrary view with three major conclusions; (1) in the long-run, majority of the industries are unaffected by volatility, but an unexpected large share of those that are affected respond positively to increased risk. (2) That sensitivity of risk differs markedly by industrials sectors, so in effect, Brazil's agricultural export are particularly harmed but United States' import of machinery are not affected in any way. (3) That products with minimal share of overall trade are more likely to respond to increase in uncertainty than major exports. Hence, share of trade volume is considerably important in trade response to exchange rate volatility. Thus, Aftab et al. (2015) conclude that exchange rate boost trade flow in most of the analysed sectors. Hooper and Kohlhagen (1978), Bahmani-Oskooee and Payestech (1993), Tharakan (1999), Doyle (2001) and Tarawalie (2010) reports show a positive relationship but sometimes not significant. Moreover, Bahmani-Oskooee and Goswami (2004) reasoned that Japans exports are not elastic to real exchange rate but her imports are more elastic.

Chiu, Lee, and Sun (2010), based on panel cointegrated framework, believes there is a long-run negative relationship between the real exchange rate and U.S bilateral trade balance. Similarly, Hsing and Sarvides (1996) also based their study in South Korea and found that depreciation of currency has little impact on trade balance but Chang (2009) indicates that exchange rate is major determinant of South Korea's trade. Wang, Lin, and Yang (2012), concluded that real appreciation of the Chinese Yuan has no overall long-run effect on China's trade balance. This result was dependent on the outcome which shows that real appreciation of Yuan has decreasing and increasing long-run effects in three (3) and five (5) respectively, of the eight (8) China trading partners under consideration in their research. Jibrilla and Shehu (2015) argued Nigeria trade balance does not instantly affected by Nigeria's currency depreciation. If both exchange rate and its volatility could influence bilateral trade, there is no doubt it could play major roles in determining country's trade balance. There are two aspects of volatility; flexibility and uncertainty. The flexibility aspect of it ensure easy flow of international finances and therefor would encourage bilateral trade but the uncertainty aspect could expose one to potential high risk which could reduce trade across countries.

Regarding the impact of third country's effect, Baak (2008) and Cushman (1986) agreed that can play prominent role in redirecting the flows of bilateral trade. In an extended study that caught across industrial level, it was revealed that South Korea's key exporting industries are extremely reactive to bilateral exchange rate volatility. The study also controlled for third country's effects in short-and long-runs which affects bilateral trade negatively. Generally, her import remains typically insensitive to exchange rate fluctuations in the three pinpointed determining factors (Baek, 2014). The author further relates economic activities in real income of the country to significantly control bilateral trade movement between two countries in long- and short-runs. Many researchers have attested that income represented by GDP substantially and prominently affects bilateral trade flow, which is the bedrock of gravity model. Following the development in above literature, the sign attached to the coefficient of volatility of exchange rate seems to be ambiguous due to no clear and definite agreement 
between scholars to that effect. Therefore, justifying these arguments using Nigeria-China situation in bilateral trade relation becomes impending necessity.

\section{Methodology and Data}

\subsection{Data Collection}

All the data collected for the applicable variables used for the purpose of this paper ranges from first quarter 1992 to $4^{\text {th }}$ quarter 2014. Nigeria GDP was collected from the Central Bank of Nigeria (CBN) database and the Chinese GDP was pooled from China's National Bureau of Statistics (NBS) database. Nigeria's export and import, to and from China respectively (China-Nigeria bilateral trade) were sourced from IMF Direction of Trade Statistics database. Likewise, exchange rate and CPI were both sourced from IMF International Financial Statistics, but import and export unit value indices of Nigeria were contributory of UNCTAD.

\subsection{Data Transformation}

All variables were properly adjusted, transformed into natural logarithm and applied in the model used herein.

\subsubsection{Real GDP $\left(Y_{i t}\right.$ and $\left.Y_{j t}\right)$}

The GDP for China and Nigeria were all reported in domestic currency, Renminbi and Naira respectively. Their nominal values were adjusted for inflation following the conventional method (See Tang 2015): $\mathrm{Y}_{\mathrm{it}(\mathrm{jt})}=(\mathrm{Y} / \mathrm{CPI})$ X 100; Where CPI represents quarterly Consumer Price Index, Y is the Quarterly Nominal Gross Domestic Product and $Y_{\text {it (jt) }}$ stands for quarterly Real Gross Domestic Product for Nigeria and China respectively. China CPI was reported annually and was converted to quarterly by ipolation.

\subsubsection{Real Exchange Rate Volatility $\left(\delta_{\mathrm{ijt}}\right)$}

The real exchange volatility will be defined as the standard deviation of the monthly real exchange rates; (Baak et al 2007, Serenis and Tsounis 2014, Baak 2008, Akhtar and Hilton 1984).

$$
\delta_{i j t}=\sqrt{\frac{1}{1-n} \sum_{k=t m}^{t n}\left(P_{i j k}-\bar{P}_{i j}\right)^{2}}
$$

Where $\mathrm{t}$ denotes a quarter and $\mathrm{k}$ stands for a month. $\mathrm{P}_{\mathrm{ijk}}$ represents monthly real exchange rate, $\bar{P}_{i j}$ is the mean of $\mathrm{P}_{\mathrm{ijk}}$ from $\mathrm{k}=\mathrm{tm}$ to $\mathrm{k}=\mathrm{tn}$. tm and th are the last and first month of the quarter as included in calculating $\delta_{\mathrm{ijt}}$ respectively.

\subsubsection{Real Exchange Rate $\left(\mathrm{P}_{\mathrm{ijt}}, \mathrm{F}_{\mathrm{cit}}\right.$ and $\left.\mathrm{F}_{\mathrm{cjt}}\right)$}

The research adopted three different exchange rates; $P_{i j t}$,-China/Nigeria bilateral exchange rate, $\mathrm{F}_{\mathrm{cit}}$ and $\mathrm{F}_{\mathrm{cjt}}$ as third country's exchange rate with respect to Nigeria and China respectively. There were neither comprehensive data reports on the bilateral exchange rate nor that of the Third country. Hence, we used the ratio of their dollar exchange rates. There were all in nominal values and will be transformed to real exchange rate such that $P_{\mathrm{ijt}}=\mathrm{E}_{\mathrm{ijt}}$ $x \mathrm{~L}_{\mathrm{j} t} / \mathrm{L}_{\mathrm{it}}$. Where $\mathrm{P}_{\mathrm{ijt}}$ stands for Real Exchange Rate in quarters, $\mathrm{E}_{\mathrm{ijt}}$ is the nominal exchange rate, $\mathrm{L}_{\mathrm{jt}}$ is quarterly Price level in country $j$ and $L_{i t}$ is Price level in Nigerian Naira. Same are applicable for $F_{\text {cit and }} F_{c j t}$.

\subsubsection{Real Imports $\left(\mathrm{X}_{\mathrm{ijt}}\right.$ and $\left.\mathrm{M}_{\mathrm{ijt}}\right)$}

China import from Nigeria stands for exports and Nigeria import from China represents imports and will be noted as such henceforth. This approach was employed to ascertain the real value of trade. The real export and import volumes are defined following Baak (2008) such that, $\mathrm{X}_{\mathrm{ijt}}=\left(\mathrm{EX}_{\mathrm{ijt}} / \mathrm{XUV}_{\mathrm{it}}\right)$ x 100; (take $\mathrm{i}=$ Nigeria, $\mathrm{j}=$ China). $\mathrm{X}_{\mathrm{ijt}}$ represents real import from Nigeria to China, $\mathrm{EX}_{\mathrm{ijt}}$ is China import from Nigeria; and $\mathrm{XUV}_{\mathrm{it}}$ stands for the import unit value index of China. Therefore, $M_{\mathrm{ijt}}=\left(\mathrm{IM}_{\mathrm{ij}} / \mathrm{MUV}_{\mathrm{it}}\right) \times 100$; (take $\mathrm{i}=$ Nigeria, $\mathrm{j}=$ China). $\mathrm{M}_{\mathrm{ijt}}$ stands for the real import from China to Nigeria, $\mathrm{IM}_{\mathrm{ijt}}$ denotes import from China to Nigeria; and $\mathrm{MUV}_{\mathrm{it}}$ is import unit value index of Nigeria.

\subsection{Methodology}

\subsubsection{Estimating the Export and Import Function}

This paper is aimed at estimating the short-run dynamic and the long-run relationship between export and import and the related exchange rate variables that explains them, using Nigeria-China trade as a study focus. This research would like to adopt the theoretical framework developed by Bahmani-Oskooee and Ardalani (2006) stated in its simplicity as follows:

$$
\begin{aligned}
& \mathrm{X}=\mathrm{X}\left(\mathrm{Y}^{*} \mathrm{ER}\right) \\
& \mathrm{M}=\mathrm{M}(\mathrm{Y}, \mathrm{ER})
\end{aligned}
$$


Where X-Value of exports, M-Value of imports, $\mathrm{Y}=$ Real domestic GDP, $\mathrm{Y}^{*}=$ Real GDP of trading partners, and ER exchange rate variables.

Baek (2014), Baek (2013) and Baak (2008) elucidate that the exchange volatility has significant effect on bilateral trade. It could also be articulated that due to ever-presence of international competition, it is pertinent that the third-party effect be captured in the model. In this paper Japan will be taken as a direct competitor to China in China-Nigeria trade relation since they are from the same region with significant trade with Nigeria. Besides, Japan was the major trade partner to Nigeria before being usurp by China as the leading supplier from East to Nigeria. Hence equation (1) and (2) will be rewritten as follows:

$$
\begin{aligned}
& \ln \mathrm{X}_{\mathrm{ijt}}=\alpha_{1}+\beta_{10} \ln \mathrm{Y}_{\mathrm{jt}}+\beta_{11} \ln \mathrm{P}_{\mathrm{ijt}}+\beta_{12} \ln \delta_{\mathrm{ijt}}+\beta_{13} \ln \mathrm{F}_{\mathrm{cit}}+\beta_{14} \mathrm{D}+\varepsilon_{\mathrm{it}} \\
& \ln \mathrm{M}_{\mathrm{ijt}}=\alpha_{2}+\beta_{20} \ln \mathrm{Y}_{\mathrm{it}}+\beta_{21} \ln \mathrm{P}_{\mathrm{ijt}}+\beta_{22} \ln \delta_{\mathrm{ijt}}+\beta_{23} \ln \mathrm{F}_{\mathrm{cjt}}+\beta_{24} \mathrm{D}+\varepsilon_{\mathrm{jt}}
\end{aligned}
$$

Given, $\mathrm{i}=$ Nigeria, $\mathrm{j}=$ China, $\mathrm{t}=$ time (Quarterly)

$\ln \mathrm{X}_{\mathrm{ijt}}$ represents real import from Nigeria to China at given time (t), $\ln \mathrm{M}_{\mathrm{ijt}}$ represents real import from China to Nigeria at given time (t), $\ln \mathrm{Y}_{\mathrm{jt}}$ is real GDP of China, $\ln \mathrm{Y}_{\mathrm{it}}$ is the real GDP of Nigeria, $\ln \mathrm{P}_{\mathrm{ijt}}$ stands for real bilateral exchange rate, $\ln \delta_{\mathrm{ijt}}$ is bilateral exchange rate volatility (China-Nigeria), $\ln \mathrm{F}_{\mathrm{cit}}$ and $\ln \mathrm{F}_{\mathrm{cjt}}$ stands for Japan-Nigeria real bilateral exchange rate and Japan-China real bilateral exchange rate which captures the effect of third country competitor and $\varepsilon_{\mathrm{it}}$ and $\varepsilon_{\mathrm{jt}}$ are white noise residuals. Note that ${ }_{\mathrm{t}}$ is in quarters. D is a dummy variable which is set such that $\mathrm{D}=1$ at period when Nigeria is democratic and zero (0) otherwise.

Given equation (4) and (5), the expectation is that increasing economic activities measured (real GDP) will encourage import and export, therefore, $\beta_{10}$ and $\beta_{20}$ are expected to be greater than zero $\left(\beta_{10}>0\right.$ and $\left.\beta_{20}>0\right)$. If on the other hand, real depreciation of the naira increases Nigeria's export and decreases its import by reducing export prices and inflating import values, then $\beta_{11}>0$ and $\beta_{21}<0$ respectively. Following the development in literature, the sign of the coefficient of volatility of exchange rate seems to be ambiguous due to most disagreement between scholars in this area. Here, it will be assumed that if an increase in volatility causes bilateral trade to decrease through increase in uncertainty on future prices, one would expect the estimated $\beta_{12}$ and $\beta_{22}$ to be negative. Similarly, if increase in Japan-Nigeria bilateral real exchange rate (high $\ln \mathrm{F}_{\text {cit }}$ ) on one hand and Japan-China bilateral real exchange rate (high $\ln \mathrm{F}_{\mathrm{cjt}}$ ) causes a decrease in China import from Nigeria and Nigeria import from China respectively, then $\beta_{13}$ and $\beta_{23}$ are expected to be less than zero $\left(\beta_{13}<0\right.$ and $\left.\beta_{23}<0\right)$.

\subsubsection{The ARDL Bounds Testing Approach to Cointegration}

Autoregressive-Distributed Lag (ARDL) model is applied to determine the long- and short-run relationship of the variables. Unlike the conventional cointegration method (like Johansen, 1995), ADRL captures the short-run and long-run parameters simultaneously. This method does not require variables to be established in the same order of integration (that is integrated of $I(0)$ or $I(1)$ ). Therefore, it presents a convenient tool to examine dynamic interaction when variables used in the model are not known with certainty whether the series are $I(1)$ or $I$ (0). Pesaran et al. (2001) reveals that the F-test can be applied to test the joint significant of the lagged-levels of variables in ARDL model and determines whether variables included in the model are $I(1)$ or $I(0)$. An upper critical value tabulated by Pesaran et al. (2001), assumes that all variables are $I(1)$ or non-stationary while lower variable critical value assumes they are all stationary. If computed F-stat falls above the upper bound of critical value, the selected variables are said to be cointegrated. Alternatively, Banerjee et al. (1998) noted that a negative and significant error-correction term $\mathrm{ec}_{\mathrm{m}-1}$ could be used as another criterion to define whether there is a long-run relationship or not.

Equation (4) and (5) above will be transformed to general form of Auto-regressive Distributed Lag Model (ARDL) as follows:

$$
\begin{aligned}
\Delta \ln \mathrm{X}_{\mathrm{ijt}}= & \alpha_{1}+\beta_{10} \mathrm{D}_{\mathrm{t}}+\beta_{11} \ln \mathrm{X}_{\mathrm{ijt}-1}+\beta_{12} \ln \mathrm{Y}_{\mathrm{jt}-1}+\beta_{13} \ln \mathrm{P}_{\mathrm{ijt}-1}+\beta_{14} \ln \delta_{\mathrm{ijt}-1}+\beta_{15} \ln \mathrm{F}_{\mathrm{cit}-1}+\sum_{i=1}^{p} \beta_{16} \Delta \ln \mathrm{X}_{\mathrm{ijt}-1}+ \\
& \sum_{i=1}^{p} \beta_{17} \Delta \ln \mathrm{Y}_{\mathrm{jt}-1}+\sum_{i=1}^{p} \beta_{18} \Delta \ln \mathrm{P}_{\mathrm{ijt}-1}+\sum_{i=1}^{p} \beta_{19} \Delta \ln \delta_{\mathrm{ijt}-1}+\sum_{i=1}^{p} \beta_{31} \Delta \ln \mathrm{F}_{\mathrm{cjt}-1}+\varepsilon_{\mathrm{ijt}} \\
\Delta \ln \mathrm{M}_{\mathrm{ijt}}= & \alpha_{2}+\beta_{20} \mathrm{D}_{\mathrm{t}}+\beta_{21} \ln \mathrm{M}_{\mathrm{ijt}-1}+\beta_{22} \ln \mathrm{Y}_{\mathrm{it}-1}+\beta_{23} \ln \mathrm{P}_{\mathrm{ijt}-1}+\beta_{24} \ln \delta_{\mathrm{ijt}-1}+\beta_{25} \ln \mathrm{F}_{\mathrm{cjt}-1}+\sum_{i=1}^{p} \beta_{26} \Delta \ln \mathrm{M}_{\mathrm{ijt}-1}+ \\
& \sum_{i=1}^{p} \beta_{27} \Delta \ln \mathrm{Y}_{\mathrm{it}-1}+\sum_{i=1}^{p} \beta_{28} \Delta \ln \mathrm{P}_{\mathrm{ijt}-1}+\sum_{i=1}^{p} \beta_{29} \Delta \ln \delta_{\mathrm{ijt}-1}+\sum_{i=1}^{p} \beta_{41} \Delta \ln \mathrm{F}_{\mathrm{cjt}-1}+\varepsilon_{\mathrm{ijt}}
\end{aligned}
$$

The descriptive meaning of the variable remains as earlier stated, $\Delta$ represent the difference of the respective variables and (-) is a representative sign for lags (1). It should be noted that applying this model would require both dependent and independent variables to be lagged. ARDL bound test requires null hypotheses for no co-integration HO: $\alpha_{1}=\beta_{11}=\beta_{12}=\beta_{13}=\beta_{14}=\beta_{15}=\beta_{16}=\beta_{17}=\beta_{18}=0$; for equation (6) and $\alpha_{2}=\beta_{21}=\beta_{22}=\beta_{23}=\beta_{24}$ $=\beta_{25}=\beta_{26}=\beta_{27}=\beta_{28}=0$; for equation (7) to satisfy long-run relationship. 


\section{Results and Discussion}

\subsection{ARDL Bound Testing for Co-Integration}

Deciding the number of required lags in the model is very fundamental. Baek (2014) and Bahmani-Oskooee and Nasir (2004) agreed that lag selection sensitively affects the result of the F-statistic. Using VAR Lag selection criteria with emphasis on AIC, lag 4 was selected for all analyses. The result for the bound test for co-integration are posted in Table 1 and satisfied the assumptions of both Pesaran et al. (2001) and Banerjee et al. (1998); all the F-statistics fall outside the lower and upper bounds and the $\mathrm{ec}_{m-l}$ were negative and significant. First the F-statistics are 9.5852 and 5.4964 for export and import functions respectively which are statistically significant at $1 \%$. Again, $\mathrm{ec}_{m-1}$ for both the export and import functions are -0.9088 and -0.3548 in that order, and statistically significant at $1 \%$ to establish the existence of long run relation.

Table 1. Result of cointegration bound test

\begin{tabular}{cccccc}
\hline Export & \multicolumn{5}{c}{ Import } \\
\hline F-statistics & $-0.9088^{* * *}$ & $\mathrm{ec}_{m-1}$ & & F-statistics & $\mathrm{ec}_{m-1}$ \\
\hline 9.5852 & & $(-8.5756)$ & 5.4964 & $-0.3548^{* * * *}$ & $(-6.7931)$ \\
\hline Sig. Level & $10 \%$ & $5 \%$ & $2.50 \%$ & $1 \%$ \\
& I0 Bound & 2.08 & 2.39 & 2.7 & 3.06 \\
I1 Bound & 3 & 3.38 & 3.73 & 4.15 \\
\hline
\end{tabular}

Note. number is parenthesis denote the T-statistics and $* * *$ represent $1 \%$ level of significance. F-statistic were determined with unrestricted intercept and no trend.

\subsection{Estimated Short-and Long-Run Co-Efficient for Export and Import Equations}

Table 2 shows the result of estimated short-run coefficient being represented by ARDL error correction model for export and import models while Table 3 displays the corresponding long-run results. Considering the export equation, there is an indication that China national income $\left(\mathrm{Y}_{\mathrm{jt}}\right)$ is a positive determinant of China's import from Nigeria $\left(X_{\mathrm{ijt}}\right)$. This signifies that growing real income in China motivates more import from Nigeria by over six percent in the short-run, with 5\% level of significance, all things being equal. The result is the same in the long but with a reduced coefficient of 1.1293 and statistically significant at $5 \%$. The result shows similarity to what is obtainable in recent literature in international trade.

Table 2. Error correction representation for selected ARDL model

\begin{tabular}{cccccc}
\hline & Export $\left(\ln \mathrm{X}_{\mathrm{ijt}}\right)$ & & \multicolumn{3}{c}{ Import $\left(\ln \mathrm{M}_{\mathrm{ijt}}\right)$} \\
\hline Variable & Co-efficient & T-statistics & Variable & Co-efficient & T-statistics \\
\hline$\Delta \ln \mathrm{Y}_{\mathrm{jt}}$ & $6.4969^{* *}$ & 2.2352 & $\Delta \ln \mathrm{Y}_{\mathrm{it}}$ & $0.4610^{* *}$ & 2.6492 \\
$\Delta \ln \mathrm{P}_{\mathrm{ijt}}$ & $2.6599 * * *$ & 3.0240 & $\Delta \ln \mathrm{P}_{\mathrm{ijt}}$ & $-1.4238^{* * *}$ & -3.7803 \\
$\Delta \ln \delta_{\mathrm{jjt}}$ & $0.1604 *$ & 1.9303 & $\Delta \ln \delta_{\mathrm{ijt}}$ & $-0.0258^{*}$ & -1.8759 \\
$\Delta \ln \mathrm{F}_{\mathrm{cit}}$ & -0.1798 & -0.0811 & $\Delta \ln \mathrm{F}_{\mathrm{cjt}}$ & $-1.1321 * *$ & -2.6658 \\
$\Delta D$ & 3.6992 & 1.0825 & $\Delta D$ & $1.1782^{* *}$ & 2.0847 \\
$\mathrm{ec}_{\mathrm{m}-1}$ & $-0.9088^{* * *}$ & -8.5756 & $\mathrm{ec}_{\mathrm{m}-1}$ & $-0.3548 * * *$ & -6.7931 \\
\hline
\end{tabular}

Note. The asterisks $* * *, * *$ and $*$ denotes significance at $1 \%, 5 \%$ and $10 \%$ levels respectively, determined with unrestricted intercept and no trend.

Though the co-efficient of real exchange rate $\left(\mathrm{P}_{\mathrm{ijt}}\right)$ and exchange rate volatility $\left(\delta_{\mathrm{ijt}}\right)$ are envisaged as not significant determinants in the long-run for export model, there were very much sensitive in the short-run with $1 \%$ and $10 \%$ statistical significance for real exchange rate and volatility respectively. This indicates that as Naira devalues against the Renminbi, export from Nigeria to China become more intense, howbeit, in the short-run. Numerically, a percentage decrease in the value of naira against Renminbi will increase China's import from Nigeria by over 2.6 percent in the short-run ceteris paribus. On the other hand, the bilateral exchange rate volatility was seen to also have positive influence in China's import from Nigeria with coefficient of 0.1604 in the short-run. That means that even if the naira is highly unstable with respect to renminbi, the prices of the materials or products from Nigeria could still make it attractive for China to buy, besides, there is less competition resulting to a positive influence in the face of exchange rate volatility. 
Also, from the export model, result shows that third country competitor's effect $\left(F_{\mathrm{cjt}}\right)$ has much negative effect on China's import from Nigeria in the long run. At least, a percentage depreciation of Japanese Yen will decrease China's import from Nigeria as focus will be shifted to buying from Japan since devaluation ensure lower prices compared to international market development. Though, this is just theoretical as Japan and Nigeria have less common goods that could led to such export competition. Therefore, has little practical sense. The result was 5\% significant in the long run, though it possesses negative coefficient in the short-run but not statistically significant to enable us make an inference.

Emphasizing on the import equation, the estimated co-efficient suggest that real national income of Nigeria $\left(\ln \mathrm{Y}_{\mathrm{it}}\right)$ is positive as well as significant determinants of Nigeria's import from China at $5 \%$ level of significance in both long-and short-run. As real income grows in Nigeria, her importation from China inevitably increases, though, the magnitude is higher in long-run as it posted higher coefficient of 0.9878 compared to coefficient of 0.4610 in the short-run. These signs are similar to the outcomes in recent literature especially when using gravity model.

Other significant results in the long run are $\ln \mathrm{P}_{\mathrm{ijt}}$ and $\ln \delta_{\mathrm{ijt}}$ at $5 \%$ and $10 \%$ significant level respectively. Both of which varies inversely as $\ln \mathrm{M}_{\mathrm{ijt}}$ insinuating that in the long-run, the devaluation of naira and its unexpectedness tend to reduce Nigeria's importation from China. Economically, depreciation of Naira against the Renminbi will mean high prices of goods and services from China, assuming all other controlling economic factors from both countries are held constant. The result is similar in the short-run, and statistically significant at $1 \%$ and $10 \%$ level for $\ln \mathrm{P}_{\mathrm{ijt}}$ and $\ln \delta_{\mathrm{ijt}}$ in that order. High volatility of naira against renminbi would generally make Nigeria external consumption lesser which could as well particularly affect her business with China.

Table 3. Estimated long-run co-efficient of export and import

\begin{tabular}{cccccc}
\hline & Export $\left(\ln \mathrm{X}_{\mathrm{ijt}}\right)$ & & \multicolumn{3}{c}{ Import $\left(\ln \mathrm{M}_{\mathrm{ijt}}\right)$} \\
\hline Variable & Co-efficient & T-statistics & Variable & Co-efficient & T-statistics \\
\hline $\ln \mathrm{Y}_{\mathrm{jt}}$ & $1.1293^{* *}$ & 2.3420 & $\ln \mathrm{Y}_{\mathrm{it}}$ & $0.9878^{* *}$ & 2.1461 \\
$\ln \mathrm{P}_{\mathrm{ijt}}$ & -1.0884 & -0.7267 & $\ln \mathrm{P}_{\mathrm{ijt}}$ & $-1.8034 * *$ & -2.0983 \\
$\ln \delta_{\mathrm{ijt}}$ & 0.0079 & 0.0415 & $\ln \delta_{\mathrm{ijt}}$ & $-0.2579 *$ & -1.8604 \\
$\ln \mathrm{F}_{\mathrm{cit}}$ & $-4.3902 * *$ & -2.1797 & $\ln \mathrm{F}_{\mathrm{cjt}}$ & 0.8445 & 0.9004 \\
$D$ & $3.5264 *$ & 1.9419 & $D$ & $5.0393 * *$ & 9.9070 \\
$C$ & -0.6372 & -0.0391 & $C$ & -2.9209 & -0.2439 \\
\hline
\end{tabular}

Note. The asterisks $* * *, * *$ and $*$ denotes significance at $1 \%, 5 \%$ and $10 \%$ levels respectively, determined with unrestricted intercept and no trend.

Third country competitor's effect $\left(\mathrm{F}_{\mathrm{cjt}}\right)$ is envisaged to be more of a short-run phenomenon in this regard with negative co-efficient at 5\% significant level. The negative co-efficient implies that as Japanese Yen experience real depreciation against Nigerian Naira over time, imports from China will potentially reduce as focus will be shifted to buying from Japan with its devaluation ensuring comparable lower prices. Japan is of course a major supplier of Nigeria's most industrial and other technically advanced products, though in the last decade, attention have been shifted to purchase of China made goods due to its price competitiveness but analysts still believe that Japan made goods are more superior in quality. Therefore, if Japan's prices could be lower by means of exchange rate devaluation, they could attract more businesses from Nigeria.

By and large, the dummy was almost statistically significant in all cases except for error correction model for export equation. This shows the significance of Nigeria political regimes in enhancing China-Nigeria bilateral trade, revealing that the trade relation is friendlier in a democratic dispensation. Even though China are viewed as not being democratic themselves, their trade relations with Nigeria are still sensitive in this regard.

In it all, with the absolute value of the real bilateral exchange rate greater than one, one would envisage that depreciation of the real (Naira/Renminbi) exchange rate will tend to ameliorate the negative trade balance Nigeria has with China contrary to the idea of Jibrilla and Shehu (2015). In other words, a percentage increase in real exchange rate in this case will generate more than a percentage increase in Nigeria's export to China and also more than a percentage decrease her import from China.

\subsection{Stability Test}

Stability test are very crucial to ascertain not only the fitness of the model but also their stability as any chance of variability will be detrimental and would renders the models undependable. Therefore, CUSUM and CUSUM of Square were applied to assess the model's stability as applied by Pesaran et al. (1997) and largely developed by 
Brown et al. (1975). The assumption being that the line of the plotted cumulative sum of recursive residuals and cumulative sum of squares of recursive residuals must be within the boundaries to reject the HO: All co-efficient in the model are not stable.
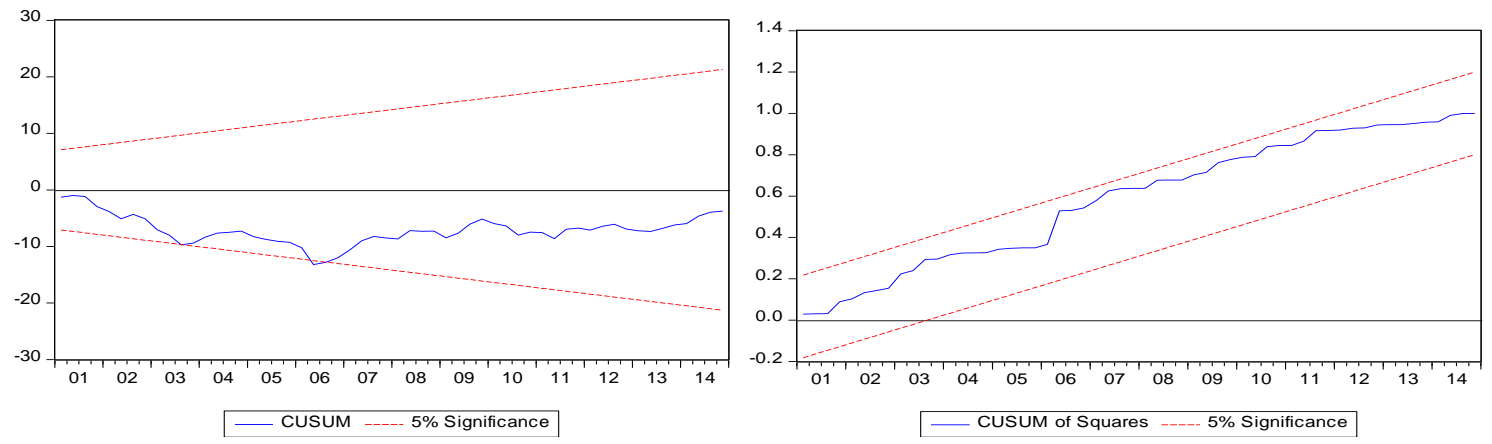

Figure 2. Plot of CUSUM and CUSUM of squares for export model
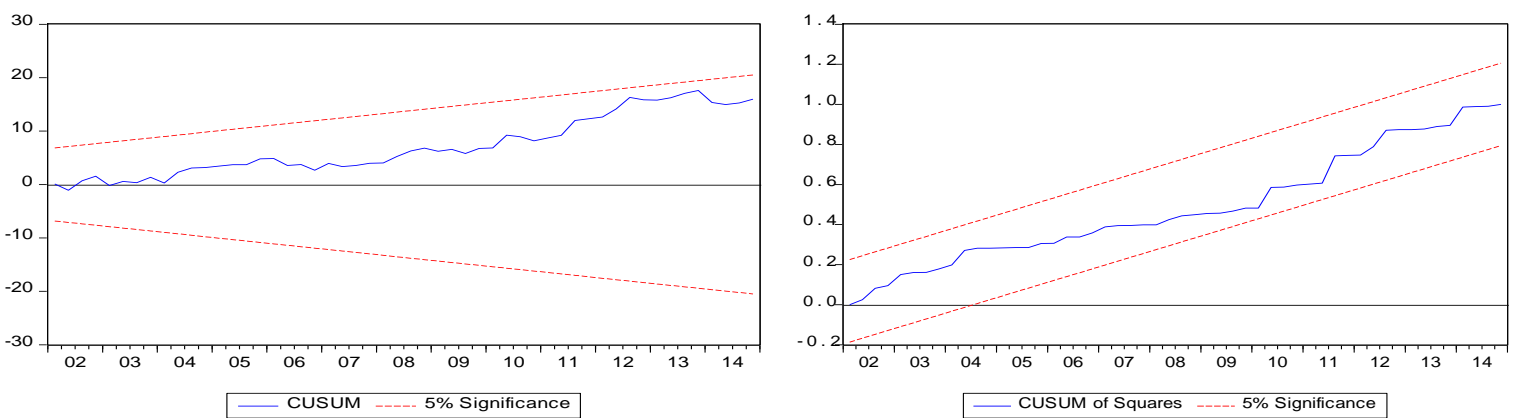

Figure 3. Plot of CUSUM and CUSUM of squares for import model

However, the CUSUM and CUSUM of Squares test graphs plotted at 5\% level significance indicate perfect stability and annuls any specification errors. This implies that the short run co-efficient in the ECM model are stable and therefore dependable. Other stability test is shown in table 4 which indicates that there are neither issue of serial correlation nor problem of heteroscedasticity. The respective null hypotheses were rejected as all probabilities were $>0.05 .1$

Table 4. Diagnostics tests

\begin{tabular}{ccc}
\hline Equation & Export & Import \\
\hline $\mathrm{R}^{2}$ & 0.8611 & 0.9932 \\
$\check{\mathrm{R}}^{2}$ & 0.7941 & 0.989 \\
$\tilde{\mathrm{U}}$ & $1.9475(0.3777)$ & $5.5802(0.0614)$ \\
$\mathrm{S} \mathrm{C}$ & $0.9427(0.3959)$ & $1.5929(0.2135)$ \\
$\mathrm{HT}$ & $0.6992(0.8438)$ & $1.0593(0.4184)$ \\
\hline
\end{tabular}

Note. $\mathrm{R}^{2}$ is the R-square, $\check{\mathrm{R}}^{2}$ is the Adjusted R-square, $\tilde{\mathrm{U}}$ is Jarque-Bera Normality test, $\mathrm{SC}$ is the Breusch-Godfrey serial correlation Lagrange Multiplier stat and HT is Breusch-Pagan-Godfrey Heteroscedasticity test. Numbers in parentheses are probabilities.

\section{Conclusion}

China is an emerging trade partner to Nigeria with increasing trade both in value and volume. This research work examined the effects of real exchange rate movement on bilateral trade between China and Nigeria taking into consideration the roles of volatility, third country's effect and Nigeria political regimes. An Autoregressive-Distributed Lag (ARDL) technique was used to determine the long-and-short run co-efficient for both export and import models. There are indications that both countries' real income is positive determinants of import and export respectively. Nigeria-China bilateral exchange rate varies directly as export and inversely as 
import both in short-and long-run. Since the absolute value of real bilateral exchange rate is greater than one in both equations, one can conclude that depreciation of Naira against the Renminbi will also tend to improve Nigeria balance of trade with China which has been negative. Exchange rate volatility respond differently to China-Nigeria trade in both fronts-negative to Nigeria's import from China and positive to her export to China.

This implies that Nigeria-China bilateral exchange rate is an obvious determinant of China-Nigeria trade and one should not neglect the serious threat of third country's bilateral exchange rate in determining bilateral trade volume. Also, given the present economic set up, Nigeria's consistence trade imbalance with China will persist even as the country's economy grows but can be corrected by currency devaluation while working towards self-reliance. Hence, both countries should endeavour to improve internal prices and allow market forces to determine currency value. Lastly, improvement in Nigeria's democratic value would strengthen this bilateral trade relation.

\section{References}

Abdol, S. S. (2009). China's Exchange Rate Policy and the United States' Trade Deficits. Journal of Economic Studies, 36(1), 36-65. https://doi.org/10.1108/01443580910923795

Aftab, M., Syed, K. B. S., Ahmad, R., \& Ismail, I. (2015). Exchange-Rate Variability and Industry Trade Flows between Malaysia and Japan. The Journal of International Trade \& Economic Development: An International and Comparative Review, 25(4), 453-478. https://doi.org/10.1080/09638199.2015.1065901

Agubamah, E. (2014). Bilateral Relations: Periscoping Nigeria and China Relations. European Scientific Journal, 10(14), 63-70

Aguirre, A., Ferreira, A., \& Notini, H. (2007). The Impact of Exchange Rate Volatility on Brazilian Manufactured Exports. Económica, La Plata, 53(1-2), 1-19.

Akhtar, M. A., \& Hilton, R. S. (1984). Effects of Exchange Rate Uncertainty on German and U.S Trade. Federal Reserve Bank of New York Quarterly Review/Spring, 9, 7-16.

Anderlini, J., \& Hornby, L. (2014). China Overtakes U.S as World's Largest Goods Trader. Financial Times.

Ariuna, T., Gibson, N., \& Inoussa, B. (2015). Commodity Exports to China and Economic Growth. Nankai Business Review International, 6(4), 401-416. https://doi.org/10.1108/NBRI-11-2014-0041

Arize, A. C., Osang, T., \& Slottje, D. J. (2000). Exchange-Rate Volatility and Foreign Trade: Evidence from Thirteen LDC's. Journal of Business and Economic Statistics, 18, 10-17.

Azu, N. P., \& Abu-Obe, E. (2016). Economic Determinants of Nigeria's Trade with China: A Cointegration Approach. International Journal of Economics and Finance, 8(3), 214-224. https://doi.org/10.5539/ijef.v8n3p214

Baak, S. (2008). The Bilateral Real Exchange Rate and Trade between China and the U.S. China Economic Review, 19(2), 117-127. https://doi.org/10.1016/j.chieco.2008.02.003

Baak, S. J., Al-Mahmood, M. A., \& Vixathep, S. (2007). Exchange Rate Volatility and Exports from East Asian Countries to Japan and the USA. Applied Economics, 39(8), 947-959. https://doi.org/10.1080/00036840500474231

Baek, J. (2013). Does the Exchange Rate Matter to Bilateral Trade between Korea and Japan? Evidence from Commodity Trade Data. Economic Modelling, 30, 856-862. https://doi.org/10.1016/j.econmod.2012.11.020

Baek, J. (2014). Exchange Rate Effects on Korea-U.S. Bilateral Trade: A new Look. Research in Economics, 68(3), 214-221. https://doi.org/10.1016/j.rie.2014.05.002

Bahmani-Oskooee, M. (2002). Does Black Market Exchange Rate Volatility Deter the Trade Flows? Iranian Experience. Applied Economics, 34(18), 2249-55. https://doi.org/10.1080/00036840210138455

Bahmani-Oskooee, M., \& Ardalani, Z. (2006). Exchange Rate Sensitivity of U.S. Trade Flows: Evidence from Industry Data. Southern Economic Journal, 72(3), 542-559. https://doi.org/10.2307/20111832

Bahmani-Oskooee, M., \& Goswami, G. G. (2004). Exchange Rate Sensitivity of Japan's Bilateral Trade Flows. Japan and the World Economy, 16(1), 1-15. https://doi.org/10.1016/S0922-1425(03)00016-1

Bahmani-Oskooee, M., \& Nasir, A. B. M. (2004). ARDL Approach to Test the Productivity Bias Hypothesis. Review of Development Economics, 8(3), 483-488. https://doi.org/10.1111/j.1467-9361.2004.00247.x

Bahmani-Oskooee, M., \& Payesteh, S. (1993). Does Exchange Rate Volatility Deter Trade Volume of LDCs? Journal of Economic Development, 18(2), 189-205. 
Bahmani-Oskooee, M., Harvey, H., \& Hegerty, S. W. (2013). The Effects of Exchange-Rate Volatility on Commodity Trade between the US and Brazil. North-American Journal of Economics and Finance, 25, 70-93. https://doi.org/10.1016/j.najef.2013.03.002

Banerjee, A., Dolado, J., \& Mestre, R. (1998). Error Correction Mechanism Tests for Cointegration in A Single-Equation Framework. Journal Time Series Analysis, 19(3), 267-283. https://doi.org/10.1111/1467-9892.00091

Brown, R. L., Durbin, J., \& Evans, J. M. (1975). Techniques for Testing the Constancy of Regression Relations over Time. Journal of the Royal Statistical Society, Series B, 37(2), 149-163. http://www.jstor.org/stable/2984889

Chang, B. K. (2009). Korea Bilateral Trade Balance and Exchange rate sensitivity: Evidence from Panel Approach. Journal of Korea Trade, 13(1), 1-19. http://www.dbpia.co.kr/Article/NODE0145152

Chiu, Y. B., Lee, C. C., \& Sun, C. H. (2010). The U.S. Trade Imbalance and Real Exchange Rate: An Application of the Heterogeneous Panel Cointegration Method. Economic Modelling, 27, 705-716. https://doi.org/10.1016/j.econmod.2010.01.011

Cushman, D. (1983). The Effects of Real Exchange Rate Risk on International Trade. Journal of International Economics, 15, 45-63. https://doi.org/10.1016/0022-1996(83)90041-7

Cushman, D. O. (1986). Has Exchange Risk Depressed International Trade: The Impact of Third Country Exchange Risk. Journal of International Money and Finance, 5(3), 361-379. https://doi.org/10.1016/0261-5606(86)90035-5

Cushman, D. O. (1988). U.S. Bilateral Trade Flows and Exchange Risk during the Floating Period. Journal of International Economics, 24(3-4), 317-330. https://doi.org/10.1016/0022-1996(88)90040-2

Dell'Ariccia, G. (1999). Exchange Rate Fluctuations and Trade Flows: Evidence from the European Union. IMF Staff Papers, 46, 315-34

Dickey, D. A., \& Fuller, W. A. (1979). Distribution of the Estimators for Autoregressive Time Series with a Unit Root. Journal of the American Statistical Association, 74(366a), 427-431. https://doi.org/10.1080/01621459.1979.10482531

Doganlar, M. (2002). Estimating the Impact of Exchange Rate Volatility on Exports: Evidence from Asian Countries. Applied Economics Letter, 9(13), 859-863. https://doi.org/10.1080/13504850210150906

Doyle, E. (2001). Exchange Rate Volatility and Irish-UK Trade, 1979-1992. Applied Economics, 33(2), 249-265. https://doi.org/10.1080/00036840122999

Dritsaki, C. (2013). Casual Nexus between Economic Growth, Export and Government Debt: The Case of Greece. Procedia Economics and Finance, 5, 251-259. https://doi.org/10.1016/S2212-5671(13)00031-2

Guajarati, D. N. (2006). Essentials of econometrics (Vol. 2, 3rd ed). McGraw-Hill/Irwin.

Hassan, M. (2013). Volatility of Exchange Rate Effecting Trade Growth- A Case of Pakistan with US, UK and UAE. European Scientific Journal, 9(22), 277-288.

Hooper, P., \& Kohlhagen, S. (1978). The Effect of Exchange Rate Uncertainty on the Prices and Volume of International Trade. Journal of International Economics, 8, 483-511. https://doi.org/10.1016/0022-1996(87)90001-8

Hsing, H. M., \& Savvides, A. (1996). Does a J-curve exist for Korea and Taiwan? Open Economies Review, 7, 126-145. https://doi.org/10.1007/BF01891900

Igue, N. N., \& Ogunleye, T. S. (2014). Impact of Real Exchange Rate on Trade Balance in Nigeria. African Development Review, 26(2), 347-358. https://doi.org/10.1111/1467-8268.12086

Jibrilla, A., \& Shehu, M. T. (2015). Asymmetric Cointegration between Exchange Rate and Trade Balance in Nigeria. Cogent Economics \& Finance, 3, 1045213. https://doi.org/10.1080/23322039.2015.1045213

Kabassi, F. A. (2012). A Tale of Two Superpowers: Nigeria and China Relations. Master's Theses. University Of San Francisco, Paper 35.

McKinnon, R. I. (2006). Currency manipulator? Wall Street Journal, 20 April, A14.

Monaghan, A. (2014). China Surpasses US as World's Largest Trading Nation. The Guardian, $10^{\text {th }}$ January.

Muhammad, S. D., Azu, N. P., \& Oko, N. F. (2018). Influence of Real Exchange Rate and Volatility on FDI 
Inflow in Nigeria. International Business Research, 11(6), 73-82. https://doi.org/10.5539/ibr.v11n6p73

Nabine, D. W. (2009). The Impact of Chinese Investment and Trade on Nigeria Economic growth. African Trade Policy Center No.77.

Olugbenga, A. O., \& Oluwole, O. (2008). Exchange Rate Volatility and Export Growth in Nigeria. Applied Economics, 40(12), 1547-1556. https://doi.org/10.1080/00036840600827676

Ozturk, I. (2006). Exchange Rate Volatility and Trade: A Literature Survey. International Journal of Applied Econometrics and Quantitative Studies, 3(1), 85-102.

Peree, E., \& Steinherr, A. (1989). Exchange rate uncertainty and foreign trade. European Economic Review, 33(6), 1241-1264. https://doi.org/10.1016/0014-2921(89)90095-0

Pesaran, M. H., Shin, Y., \& Smith. R. J. (2001). Bounds Testing Approaches to the Analysis of Level Relationships. Journal of Applied Econometrics, 16, 289-326. https://doi.org/10.1002/jae.616

Pigato, M., \& Tang, W. (2015). China and Africa: Expanding Economic Ties in an Evolving Global Context. Investing in Africa Forum by World Bank, March 2015. Retrieved from http://documents.worldbank.org/curated/en/2015/03/24177102/china-africa-expanding-economic-ties-evolv ing-global-context

Qazi, M. A. H. (2012). Exports, imports and economic growth in China: an ARDL analysis. Journal of Chinese Economic and Foreign Trade Studies, 5(1), 42-55. https://doi.org/10.1108/17544401211197959

Serenis, D., \& Serenis, P. (2008). The Impact of Exchange Rate Volatility on Exports: Evidence from Four European Countries. International Conference on Applied Economics - ICOAE 2008.

Serenis, D., \& Serenis, P. (2010). Exchange Rate Volatility, the E.U. and Sectoral Exports: New Empirical Evidence from the Chemical Sector (1973-2005). Research in World Economy, 1(1), 47-55. https://doi.org/10.5430/rwe.v1n1p47

Serenisa, D., \& Tsounisb, N. (2014). Does Exchange Rate Variation Effect African Trade Flows? Procedia Economics and Finance, (14), 565-574. https://doi.org/10.1016/S2212-5671(14)00757-6

Shehu, U. R. A. (2010). Exchange Rate Volatility and Export Trade in Nigeria: An Empirical Investigation. Applied Financial Economics, 20(13), 1071-1084. https://doi.org/10.1080/09603101003724380

Tang, B. (2015). Real Exchange Rate and Economic Growth in China: A Cointegration VAR Approach. China Economic Review, 34(July), 293-310. https://doi.org/10.1016/j.chieco.2014.12.002

Tang, T. K. (2003). An Empirical Analysis of China's Aggregate Import Demand Function. China Economic Review, 14(2), 142-163. https://doi.org/10.1016/S1043-951X(03)00021-X

Tarawalie, A. B. (2010). Real Exchange Rate Behaviour and Economic Growth: Evidence from Sierra Leone Economics. South African Journal of Economic and Management Sciences, 13(1), 8-25. https://doi.org/10.4102/sajems.v13i1.195

Tung, C. Y., \& Sam, B. (2004). RMB Revaluation Will Serve China's Self-interest. China Economic Review, 15(3), 331-335. https://doi.org/10.1016/j.chieco.2004.06.003

Udala, S. O. (2010). Nigeria-China Economic Relations under the south-south Cooperation. African Journal of International Affairs, 13(1\&2), 61-88.

Wang, C. H., Lin, C. H. A., \& Yang, C. H. (2012). Short-run and Long-run Effects of Exchange Rate Change on Trade Balance: Evidence from China and Its Trading Partners. Japan and the World Economy, 24(4), 266-273. https://doi.org/10.1016/j.japwor.2012.07.001

Zhang, Z. (1999). Foreign Exchange Rate Reform, the Balance of Trade and Economic Growth: An Empirical Analysis for China. Journal of Economic Development, 24(2), 143-162.

Zhang, Z. (2001). China's Exchange Rate Reform and Exports. Economics of Planning, 34(1-2), 89-112. https://doi.org/10.1023/A:1017549828555

\section{Copyrights}

Copyright for this article is retained by the author(s), with first publication rights granted to the journal.

This is an open-access article distributed under the terms and conditions of the Creative Commons Attribution license (http://creativecommons.org/licenses/by/4.0/). 